moralsk handlende». Her forkastes ideen om legerollen som tillitsverdig uavhengig av hvem som sitter på kontoret. Slike premisser gjør ikke begrunnelsen for reservasjonsadgang mindre tvilsom.

\section{Andreas Eriksen}

andreas.eriksen@hioa.no

Andreas Eriksen (f. 1984) har en mastergrad i filosofi og er ph.d.-stipendiat ved Senter for profesjonsstudier, Høgskolen i Oslo og Akershus. Ingen oppgitte interessekonflikter.

\section{Litteratur}

1. Clemet K, Magelssen M, Jørgensen HN. Samvittighetsfrihet og fastlegers reservasjonsrett. Civita-notat nr. 17/2012, i samarbeid med Tankesmien Skaperkraft. Oslo: Civita, 2012.

\section{Re: Sjeldenhet - eget kriterium ved prioritering?}

Heiberg og medarbeidere mener at sjeldenhet av sykdommen bør være et eget kriterium ved prioritering i helsevesenet (1). Det mener jeg er en avsporing av en viktig debatt. Sjeldenhet har egenverdi bare for samlere, f.eks. av sommerfugler og frimerker. I helsevesenet driver man, forhåpentlig, ikke med samling. At sykdommen er sjelden har ikke betydning i seg selv, til forskjell fra sykdommens alvorlighetsgrad og nytte av eventuell behandling.

Sakens kjerne er vektlegging av kostnader ved behandling. Heiberg og medarbeidere har som etisk premiss at ved prioritering bør alle ha «like muligheter til helse», dvs. også om det er variasjon i kostnadene. Tiltak for personer med sjeldne sykdommer tenderer til å være svært kostbare regnet per person. Det følger at det offentlige helsevesen bør være innstilt på å akseptere høyere kostnader per vunnet QALY i forbindelse med sjeldne sykdommer enn i forbindelse med vanlige sykdommer. Men av det etiske premisset om like behandlingsmuligheter for alle følger det like mye at personer som er dyre å behandle av andre grunner enn sjeldenhet, bør tilgodeses med høyere betalingsvillighet per QALY. Skal man ha større betalingsvillighet i forbindelse med personer som er dyre pga. sjeldenhet, enn i forbindelse med personer som er dyre av andre grunner, må man ha en god grunn. Dette problemet overser Heiberg og medarbeidere.

En australsk-norsk studie tydet på at folk flest synes at kostnader ikke bør tillegges så stor vekt som prioritering etter kostnad-nytteforhold tilsier (2). Dette er et viktig tema å diskutere. Ut av det kan det komme konklusjoner som er gunstige også for personer med sjeldne sykdommer. Men det betyr altså ikke at sjeldenhet fortjener å bli eget prioriteringskriterium.

Ellers synes jeg at forfatternes omgang med QALY-begrepet er forvirrende. QALY er et uttrykk for størrelsen på helsegevinster, ikke for samfunnsmessig verdsettelse av tiltak for ulike grupper (3). I det sistnevnte kommer rettferdighetsbetraktninger inn i bildet. Det er per i dag å slå inn nokså åpne dører å si at det offentlige helsevesenets betalingsvillighet for en QALY vil måtte avhenge av omstendighetene (4).

\section{Erik Nord}

erik.nord@fhi.no

Erik Nord (f. 1948) er professor i helseøkonomi, Nasjonalt folkehelseinstitutt/Universitetet i Oslo.

Ingen oppgitte interessekonflikter

\section{Litteratur}

1. Heiberg A, Frich J, Røttingen JA. Sjeldenhet - eget kriterium ved prioritering? Tidsskr Nor Legeforen 2014; 134: 534-6.

2. Nord E, Richardson J, Street A et al. Who cares about cost? Does economic analysis impose or reflect social values? Health Policy 1995; 34: 79-94.

3. Nord E, Richardson J, Macarounas-Kirchmann K. Social evaluation of health care versus personal evaluation of health states. Evidence on the validity of four health-state scaling instruments using Norwegian and Australian surveys. Int J Technol Assess Health Care 1993; 9: 463-78.

4. Økonomisk evaluering av helsetiltak - en veileder. Oslo: Helsedirektoratet, 2012.

\section{A. Heiberg og medarbeidere svarer:}

I sitt kommentarinnlegg er Nord uenig $i$ at status som sjelden diagnose bør tillegges vekt ved prioriteringer i helsevesenet, og han hevder at vi misforstår QALY-begrepet. I vår artikkel skrev vi: «Gjennom størrelsen «kvalitetsjusterte leveår» (QALY) kan man få et mål for hvordan befolkningen verdsetter et ekstra leveår for en person i gruppe A og en person i gruppe B, og man vil kunne legge dette til grunn når man skal prioritere».

La oss presisere at vi med «verdsetter» i sitatet over viser til hvordan respondenter i en befolkning verdsetter kvaliteten på livet med en gitt tilstand eller sykdom på en skala fra 0,0 til 1,0. En av hensiktene med vår artikkel var å påpeke at dersom man ensidig innfører en øvre grense for behandlingskostnader basert på QALY, vil personer med sjeldne sykdommer i praksis ekskluderes fra muligheten til likeverdig behandling.

Nord skriver: «Men av det etiske premisset om like behandlingsmuligheter for alle følger det like mye at personer som er dyre å behandle av andre grunner enn sjeldenhet, bør tilgodeses med høyere betalingsvillighet». Vi er, som vi sier i artikkelen, enige i at det kan være andre forhold, slik som en sykdoms alvorlighet, som kan begrunne høyere betalingsvillighet for tilstander som ikke er sjeldne.

Nord etterlyser argumentasjon for at sjeldenhet er relevant som eget kriterium i en prioriteringssammenheng. Hovedargumentet i vår artikkel er: Det er en kjensgjerning at utviklings- og innovasjonskostnadene for legemidler til pasientgrupper med sjeldne sykdommer ikke er lavere enn for andre sykdommer. I og med at slike kostnader må fordeles på et færre antall pasienter, vil dette gjenspeiles i prisen på behandlingen. Det vil følgelig, som hovedregel, koste mer for samfunnet å behandle en pasient med en sjelden diagnose sammenliknet med en pasient med en vanligere sykdom.

De internasjonale ordningene for «orphan diseases» $(1,2)$ tar høyde for at utviklings- og innovasjonskostnadene for sjeldne tilstander må dekkes inn på et færre antall pasienter, og de forsøker å korrigere denne markedssvikten for å sikre likeverdige behandlingsmuligheter. Dette kan gjøres ved raskere og enklere godkjenningsprosesser, lengre markedseksklusivitet og signaler om villighet til høyere pris. Disse mekanismene er etablert politikk og praksis i Norge, Europa og USA, og viser at sjeldenhet implisitt er etablert som de facto prioriteringskriterium. Vårt poeng er at sjeldenhet også formelt bør gis en slik status slik at vi sikrer dem med sjeldne sykdommer en lik rett til behandlingsmuligheter.

\section{Arvid Heiberg \\ arvhei@ous-hf.no \\ Jan Frich}

\section{John-Arne Røttingen}

Arvid Heiberg (f. 1937) er professor og tidligere overlege ved Avdeling for medisinsk genetikk, Oslo universitetssykehus, Rikshospitalet, og medlem av nasjonal forskningsetisk komité for medisin.

Oppgitte interessekonflikter: Han har deltatt i møter arrangert av BioMarin, Genzyme og Shire og utfører forskning med henblikk på pasienter med Huntingtons sykdom, finansiert av CHDI (Cure Huntington's Disease Initiative), en USA-basert forskningsstiftelse.

Jan Frich (f. 1970) er professor ved Avdeling for helseledelse og helse$\emptyset$ konomi, Universitetet i Oslo, og overlege ved Nevrologisk avdeling, Oslo universitetssykehus.

Oppgitte interessekonflikter: Han er involvert i forskningsprosjekter om Huntingtons sykdom, inkludert studiene REGISTRY/Enroll-HD og en PET-studie av fosfodiesterase 10A, finansiert av CHDI Foundation.

John-Arne Røttingen (f. 1969) er prosjektleder for HelseOmsorg 21, divisjonsdirektør ved Nasjonalt folkehelseinstitutt og professor ved Avdeling for helseledelse og helseøkonomi, Universitetet i Oslo.

Ingen oppgitte interessekonflikter. 
Litteratur

1. Developing products for rare diseases and conditions. www.fda.gov/Forlndustry/ Developing ProductsforRareDiseasesConditions/default.htm (20.1.2014).

2. Medicines for rare diseases. www.ema.europa.eu/ema/index.jsp?curl=pages/ special_topics/general/general_content_000034.jsp\&mid=WC0b01ac $058002 \bar{d} 4 \mathrm{eb}(20.1 .2014)$.

\section{Re: Ruset i ord}

I Tidsskriftet nr. 5/2014 drøfter Hem om ein skal nytte nemninga rusmisbrukar eller rusmiddelmisbrukar (1). Eg vil argumentere for å skrote bruken av begge orda.

Orddelen «mis» har etter mitt skjøn eit moralistisk element. Bruken av ordet peiker mot at noko er gjort feil eller gale, jamfør misdåd eller mistyding. ICD har meir nøytrale, deskriptive nemningar for å kategorisere lidingar relaterte til rusbruk, til dømes skadeleg bruk (F1x.1) eller avhengnad (F1x.2).

Eg oppfattar at det å karakterisere pasientar utelukkande med lidinga si er på veg ut. Det er ikkje berre utviklinga i dagkirurgi som gjer at ein ikkje lenger snakker som «brokket i 3-senga på 213». Lat oss også innafor medisin elles snakke om «pasient med rusliding», eller rusmiddelbrukar eller rusmiddelavhengig, som Hegge tek til orde for (2). Nemningane Hem drøfter bruken av, treng vi ikkje i fagleg samanhang.

\section{Øyvind Watne}

oyvind.watne@stolav.no

Øyvind Watne (f. 1951) er overlege ved Tiller DPS, St. Olavs hospital. Ingen oppgitte interessekonflikter

\section{Litteratur}

1. Hem E. Ruset i ord. Tidsskr Nor Legeforen 2014: 134: 537.

2. Hegge PE. Språket vårt: Alle livene deres. Aftenposten 11.8.2013: 4

http://tux.aftenposten.no/spraak/spraak?action=question\&id=5099 (14.3.2013)

\section{E. Hem svarer:}

Øyvind Watne har rett. Det er en uting å karakterisere folk ut fra hvilken sykdom de har. Det har vært påpekt flere ganger

i Tidsskriftet $(1,2)$.

Men det var ikke det jeg drøftet i Språkspalten nr. 5/2014. Mitt anliggende var ordparet rusmiddelmisbruk og rusmisbruk. Selv om rusmiddelmisbruk kanskje er mest logisk, slik Per Egil Hegge har påpekt, er det kortformen rusmisbruk som er klart mest brukt. $\mathrm{Og}$ på den måten er språket demokratisk. Flertallet får som regel rett til slutt.

\section{Erlend Hem}

erlend.hem@medisin.uio.no

Erlend Hem (f. 1970) er assisterende sjefredaktør i Tidsskriftet.

Ingen oppgitte interessekonflikter.

\section{Litteratur}

1. Nylund MF. Funksjonshemmet? Tidsskr Nor Legeforen 2009: 129: 1491

2. Nakken KO. Betegnelsen epileptiker bør unngås. Tidsskr Nor Legeforen 2013 133: 1088

\section{Re: Reservasjon og det liberale dilemma}

Når forfatteren her legger frem konflikten i debatten om reservasjonsrett som et dilemma mellom et «pragmatisk» og et «idealistisk» livssyn, har han berørt en kjerne i denne kampen (1). Og han legger frem konsekvensene veldig klart: «Pragmatikeren ... mener at moral hovedsakelig kommer til uttrykk gjennom samfunnets lover.... Helsearbeidere må underordne seg disse lovene, fordi de gjennom en kontrakt forvalter en oppgave på samfunnets vegne. .... Samvittigheten er derimot en privatsak og dessuten en usikker kilde til moralsk innsikt fordi den er koplet til følelseslivet.»
I sin konklusjon overser forfatteren at når samvittighet blir gjort til kampsak, er det ikke lenger snakk om frihet til egen samvittighet som er på dagsordenen, men et ønske om å pålegge egen samvittighet på andre mennesker, og derved begrense deres handlinger. Dette, i sin ekstreme form, var grunnlaget for religionsstyrte samfunn, for eksempel Calvins innføring av Guds ord som lov i Genève på 1500-tallet. I Arizona, USA, forsøkte man nylig å etablere en lov som ga forretninger lov til å «reservere seg» mot å selge ting eller tjenester til homofile.

Problemet med tro og samvittighet som ledende prinsipp er at vi alle tror vår egen samvittighet er den rette. Bare når vi står ansikt til ansikt med å måtte underlegge oss andres samvittighet kan vi fullt ut forstå hva dette fører til. Norge er et multikulturelt, sekulært samfunn med lover som reflekterer dette. Det er mennesker i Norge som ikke tror på Gud, som ikke tror abort er synd, og som ikke tror at menneskene har evig sjel.

Jeg tror ikke reservasjonsrettdebatten egentlig dreier seg om at leger ikke kan finne en måte å følge egen samvittighet på. Jeg tror dette ble sett som en måte å vinkle abortdebatten på, for å finne en ny måte å prøve å forhindre abort på uten å si det direkte. For oss som tror på mennesket som en evig sjel, er abort hjerteskjærende. Målet må være å hjelpe kvinner til å finne alternativer og løsninger $i$ en vanskelig situasjon. Reservasjonsrett basert på samvittighet kunne føre til nekt av tjenester til alle som ikke følger min moral.

Vi må være forsiktige med å universalisere når vi i virkeligheten bare prøver å fremme egen kampsak.

\section{Hildegunn Rodrick \\ hildegunnr@gmail.com}

Hildegunn Rodrick (f. 1954) er employment specialist ved Edinburg Center for Psychiatric Recovery.

Ingen oppgitte interessekonflikter

Litteratur

1. Wyller VB. Reservasjon og det liberale dilemma. Tidsskr Nor Legeforen 2014 134: 504 .

\section{Re: Reservasjon og det liberale dilemma}

I debatten om fastlegers «behov» for «reservasjonsmulighet», og også i denne kommentarartikkelen, henvises det til legenes samvittighetsfrihet (1).

Av min bruk av hermetegn, skjønner dere sikkert mitt syn på dette spørsmålet. Det foreligger ikke noe behov for «reservasjonsmulighet» for fastleger, fordi det alt finnes en utmerket reservasjonsmulighet for leger: De kan avstå fra å inngå fastlegeavtale!

Når en lege inngår en fastlegeavtale, forplikter legen seg til å levere alle de helsetjenester felleskapet har funnet det formålstjenlig å legge inn i fastlegeordningen, inklusive tjenesten «henvisning til abort» for de kvinner som har slikt behov, og som velger å gå veien om sin fastlege. Hvis en lege av samvittighetsgrunner har problemer med å levere noen av tjenestene som fastlegene er forventet å levere, da kan legen enkelt og greit velge en annen type legestilling hvor man ikke har en slik forpliktelse.

Ergo finnes det for legeyrket en utmerket, effektiv og enkel mulighet for å unngå å komme i konflikt med sin samvittighet i dette (og andre) spørsmål. Legers samvittighetsfrihet har allerede en eksisterende beskyttelse.

\section{Kjell Ingvaldsen}

kingvald@online.no

Kjell Ingvaldsen (f. 1966) er arbeidssøker.

Ingen oppgitte interessekonflikter

Litteratur

1. Wyller VB. Reservasjon og det liberale dilemma. Tidsskr Nor Legeforen 2014 $134: 504$. 